\title{
THE USE OF ENGLISH POP SONG TO ENHANCE STUDENTS' LISTENING ABILITY
}

\author{
${ }^{\# 1}$ Sri Ariani, ${ }^{* 2}$ Khairi Iswandi \\ ${ }^{\# 1}$ English Teacher, Faculty of Culture, Management and Business (FBMB), \\ UNDIKMA, Indonesia \\ ${ }^{*}$ Student, Faculty of Culture, Management and Business (FBMB), \\ UNDIKMA, Indonesia
}

Corresponding Author Email: Sri_ariani@ikipmataram.ac.id

\section{A B S T RA C T S}

This research aims to find out the use of English Pop Song to enhance students' listening ability in the first grade of SMAN 10 Mataram in 2020/2021. The research method of this research used Classroom Action Research. The data in this research was taken based on the listening test. The subject of this research was first-grade students IPS 1 of SMAN 10 Mataram, which consisted of 25 students. This research was conducted in one cycle. The instruments of this research were taken by test and observation sheet. The main score of students listening ability of pre-test was 45 with a percentage $(12 \%)$ and the main score of post-test was 76 with a percentage $(84 \%)$. The researchers concluded that the score of the students' listening was higher than the Minimum Complete Criteria Success (KKM). So it meant that the use of English Pop Song was significant to enhance students' listening ability.
\end{abstract}

\author{
A R T I C L E I N F O \\ Article History: \\ Received: October, 2020
}

Revised: November, 2020

Published: December, 2020

\section{Keywords:}

English Pop Song,

Listening Ability,

How to cite: Ariani, S., \& Iswandi, K. (2020). The Use of English Pop Song to Enhance Students' Listening Ability. Jo-ELT (Journal of English Language Teaching) Fakultas Pendidikan Bahasa \& Seni Prodi Pendidikan Bahasa Inggris IKIP, 7(2), 112-118. doi:https://doi.org/10.33394/jo-elt.v7i2.2965

\section{INTRODUCTION}

Listening is the ability to identify what the people saying (Rost, 2013). Therefore, listening was very important to learning English exactly in learning English foreign language using media such as pop song. this study is based on the phenomenon of students' ability in listening which is found still at a low level and needs to improve. The students need to learn English in such a happy and fun way to motivate them in learning English. When the researchers interviewed English teachers, it appears that the method or media used by English teachers is quite good, however, the students still feeling bored and not happy. Utilizing pop songs in a lesson environment attracts attention. So, the researchers are interested to apply media to support the teaching-learning process.

This study was aimed to find out whether or not the use of songs significantly improves students' listening skill. Nihei (2002: 2) said listening is an important skill for the person who is learning English because in verbal communication we cannot communicate with each other without listening to the speaker's utterances and understanding them. In learning English we have to often listen to people who speak English, like a reason for the conversation, watch the movie and listen to music. Richard (2003: 5) said that Music is a performative art. It stresses movement through time and engages our suggestive sense of its passing. Music has a tendency; it normally invokes goals of various sorts, both near and far. Music has closure, a sensation not just of ending, but of expecting no more. Music also has an accent. It is a 
dynamic process of stresses and nuance that often varies in dimension from one performance to the next.

Byrne (1986: 57) suggested many goals and purpose of listening comprehension program, firstly: to use a wide variety of samples to give the learns the experience of listening by exposing learns to deference type of language, for example, formal and informal, different text types, for example, compensational or narrate. The teacher should motivate learners by pleasure, inters, and growing competence at being able to understand the spoken text without going back to written forms. Secondly, trying learners to listen for specific information of the main ideas or for reacting to specific instruction by doing anything. Learners, in this situation, maybe motivated by using tasks that are interesting to their right and which will focus on the learners 'attention on the material in an appropriate way. Then, by listening, learners should be provided with a stimulus for other activities such as discussion, reading, and writing. Lastly, giving learners opportunities to interact while listening by using different discussions, activities, and games inside the classroom.

To run out the previous goals, many activities can be considered, firstly: using stories, anecdotes, jokes, talks, commentaries are used with one speaker. Byrne maintained that' If a teacher is stalling a story or giving a talk to the class, he should try to be asking spontaneous as possible". Secondly: using conversation, discussion, and plays which are used with more than one speaker. In this site, learners should be given the background of the situations, for example: about the speakers. Thirdly: using a song either traditional of pop, this will be very interesting to learners by which learners can be asked to feel is missing words, phrases, or sentence. Finally: vicious and films can be used and it has a lot of advantages because learners can see what is happened as well as listen.

According to Brown (2003: 7) teaching is showing or helping someone or groups to learn how to do something, giving instruction guiding the study something, providing with knowledge, causing them to know or understand and learning is acquiring or getting knowledge of a subject or skill by study, experience, or instruction. In addition, in learning the English language, listening is important for communications because listeners can get good information through good listening. Zogota (2011: 40) said there are some processes of teaching listening with a song that is: Pre- Listening Information: Many popular songs are sung in such a way that the word is difficult to catch but it is often just a kind of music that students most want to listen, especially at the secondary school level. Rather than only using slow and easy to understand music in the classroom, this technique makes it possible to play music with difficulty to catch lyrics. Preparation: Obtain the full lyrics of the song and prepare them to be handed out. Then make small talk about the singer.

According to Fang (2008), in the listening Process, there is three-step, they are: Firstly: listen to the song with no text or preparation teacher ask the students what words they could catch, then ask them to write down the words and phrases that students hear and share them with the class. Secondly: The teacher plays the song but this time a read the line before playing the song or go over vocabulary. It means read line and plays a line. Students will not understand all the vocabulary nor they retain much in long-term memory, but they will understand and recognize that what the teachers are saying is indeed what is being sung. Thirdly: Pass out the full text and the teacher ask the students to listen again while they are looking at the lyric. In these 3 steps, the teacher should have taken the students to full understanding. After Listening: discuss vocabulary idioms, grammar, abbreviations, and the performance by the singer. 


\section{RESEARCH METHOD}

The researchers found the students' lack in listening skill, especially they were lack and understanding the sound and vocabulary; to solve this problem the researchers used Classroom Action Research (CAR). Action research is classroom-based research conducted by a teacher in order in order to reflect upon and evolve their teaching. It is a systematic, documented inquiry into one aspect of teaching and learning in a specific classroom.

\section{Research Design}

The researchers analyzed the data descriptively. It referred to the Cycles of Classroom Research taken from Kermis, Mc Taggart \& Nixon (2014). In this study, the procedure of action research was on how the process of the researchers in conducting this research started from the research preparation up to the end of this research. To arrange this research the researchers applied four steps such as planning, acting, observing, and reflecting.

\section{Subject}

The subject of this research was the students' class of X IPS 1 at SMAN 10 Mataram at the first-grade students with a total of 25 students.

\section{Instruments}

The researchers used instruments to measure the student's development during conducting this research. To collect data, the researchers came to the class as a teacher who gave a listening test which consisted of 20 questions, in form of filling the blank. English pop songs were played several times in front of the class, and the researchers gave a question and asked the students to fill in the missing song lyrics. In addition, an observation sheet and note tail used in this research. In this type of instrument, the researchers had the observation sheet to write and investigated the teachers' and the students' activities during the learning process. On this occasion, the researchers would not have a position as a teacher but as the observer. So that the researchers focused on how the teacher participates in the students and how respond or even the attitude of the students during the learning process. Note tail is an instrument to record all events that happen in connection with the action of the teachers or the researchers. It is also useful for knowing the student's progress in the learning process.

\section{Data Analysis}

The pre-test is the first step in collecting the data. The researchers came to the class played the audio song lyric and asked students to sing together, and the researchers gave the students a set of tests to the students to find out the level of student's knowledge dealing with material delivered. Pre-test activities conducted before teaching it is given in order words, a pre-test used to find out the ability of students about the lesson delivered.

The post-test is the last step of collecting data. This step is conducted after giving the treatment to both of group the same test-the result of the post-test is compared to the result of the pre-test that has been done so that the researchers can measure the students' listening ability and how was the method English pop song can be useful in enhancing students' listening ability in English. Also, this revealed what part of teaching material is still not comprehended by the majority of students.

This research applied the methods to analyze the data quantitative and qualitative data. The qualitative analysis is to know the phenomena that happened during the classroom action by applying English pop song technique through test and observation sheet which already explained, meanwhile, the data from the test (quantitative analysis) are investigated through counting the total average of each cycle and discovering the differences between each cycle. 


\section{RESEARCH FINDINGS AND DISCUSSION \\ Research Findings}

This research was conducted in one cycle and there were eight meeting times to conduct the data of this research. Students' scores of pre-test can be seen in table 1 .

Table 1

Students Score of Pre-test

\begin{tabular}{|c|c|c|}
\hline No & Name & Score of Pre-Test \\
\hline 1 & $\mathrm{ABS}$ & 43 \\
\hline 2 & UA & 40 \\
\hline 3 & ASF & 50 \\
\hline 4 & RAH & 57 \\
\hline 5 & $\mathrm{~A}$ & 33 \\
\hline 6 & $\mathrm{AB}$ & 63 \\
\hline 7 & IM & 27 \\
\hline 8 & DW & 63 \\
\hline 9 & $\mathrm{DA}$ & 60 \\
\hline 10 & EPA & 33 \\
\hline 11 & FR & 33 \\
\hline 12 & $\mathrm{~F}$ & 37 \\
\hline 13 & $\mathrm{FH}$ & 67 \\
\hline 14 & $\mathrm{RS}$ & 67 \\
\hline 15 & AM & 67 \\
\hline 16 & IKD & 47 \\
\hline 17 & LA & 43 \\
\hline 18 & $\mathrm{~S}$ & 37 \\
\hline 19 & LA & 43 \\
\hline 20 & MRB & 27 \\
\hline 21 & $\mathrm{AM}$ & 37 \\
\hline 22 & MRB & 37 \\
\hline 23 & MRPI & 27 \\
\hline 24 & $\mathrm{R}$ & 37 \\
\hline 25 & MRE & 60 \\
\hline \multicolumn{2}{|c|}{ TOTAL } & 1135 \\
\hline
\end{tabular}

Based on the result of the pre-test means a score of students were 45 and the result of the pre-test students means score still has under the minimum of mastering criterion. The lowest score was 27 and the hights score was 67 and the students' score percentage was $12 \%$ from the result of the pre-test, it revealed that the students in learning listening ability still low. 
Students' scores of the post-test can be seen in table 2 .

Table 2

Students Score of Post-test

\begin{tabular}{|c|l|c|}
\hline No & Name & Score of Post-test \\
\hline 1 & ABS & 70 \\
\hline 2 & UA & 63 \\
\hline 3 & ASF & 83 \\
\hline 4 & RAH & 93 \\
\hline 5 & A & 60 \\
\hline 6 & AB & 90 \\
\hline 7 & IM & 70 \\
\hline 8 & DW & 80 \\
\hline 9 & DA & 73 \\
\hline 10 & EPA & 73 \\
\hline 11 & FR & 73 \\
\hline 12 & F & 70 \\
\hline 13 & FH & 70 \\
\hline 14 & RS & 80 \\
\hline 15 & AM & 83 \\
\hline 16 & IKD & 90 \\
\hline 17 & LA & 83 \\
\hline 18 & S & 83 \\
\hline 19 & LA & 83 \\
\hline 20 & MRB & 83 \\
\hline 21 & AM & 93 \\
\hline 22 & MRB & 70 \\
\hline 23 & MRPI & 63 \\
\hline 24 & R & 63 \\
\hline 25 & MRE & 1912 \\
\hline & TOTAL & \\
\hline & & 70 \\
\hline
\end{tabular}

Based on the second-test result, the researcher concluded that the students' score improved at 76 in which there was a percentage at $84 \%$. The students improved their Listening skill with the fact that there were 21 students got the score above the MCC/KKM and 4 students under the KKM with the lower score was 60 and the higher score was 90.

The researchers concluded that starting from the research finding, the researcher conducted one cycle only because there was students' listening ability. In preliminary of the study, the researchers conducted the observation to know the condition of the students themself, whether the condition is chanced or still like the first observation conducted by the researchers. Then the researchers conducted the first-test at the first meeting, treatment at the second up to the fourth meetings, and the last meeting or the fifth meeting the researchers conducted the second-test. The students' listening achievement was improved because of the treatment using English pop song.

The mean score of students' first-test was 45 and the percentage was $12 \%$ above the KKM. There were 3 students who got a higher score and the 22 students got under the KKM while the lower score was 33, the higher score was 67 . Meanwhile, the result of students' post-test started from the mean score was 76 and the percentage was $84 \%$. There were 21 students who got a score above the KKM, and 4 students got under the KKM.

\section{Discussion}

The students were lack of vocabulary so that most of them have difficulties to understand the song lyrics (Edgar, 2010). This meant that the students have a problem with 
factual or literal comprehension that means they cannot identify what will said or what facts were stated, the other type is with interpretation, for example, categorizing new in formations. students' competence in listening skill is very low. It is shown from the students Pre-test mean score was 45 and the result of the pre-test means score was under the minimum of mastering criterion. The lowest score was 27 and the hights score was 67 and the students' score percentage was $12 \%$ from the result of the pre-test, it revealed that the students in learning listening ability still low.

The treatment gave some benefits to the students to improve their competence in listening practice. They did better than before giving the treatment. The students gave full attention and concentration to the English pop song. This can make the students became activated in doing listening to exercise in the classroom. Supported by the proper audio and sound system presented different kinds of learning but fun. Based on the second-test result, it revealed that the students' score improved at 76 with a percentage $84 \%$. The students improved their Listening skill with the fact that there were 21 students got the score above the $\mathrm{MCC} / \mathrm{KKM}$ and 4 students under the KKM with the lower score was 60 and the higher score was 90.

To find out whether there any improvement of the students listening ability, the researcher conducted the research in one cycle because it was found any improvements of students listening ability. In the preliminary of the study, the researchers conducted the observation. Then the researchers conducted the first-test at the first meeting, treatment at the second up to the fourth meetings, and the last meeting or the fifth meeting the researchers conducted the second-test. The students' listening was improved because of the treatment using English pop song.

The researchers able to know the students' development from the students' activities during the learning process, exercise, and the condition in every meeting was different, which the students enjoyed and should be focus to the teacher because the teacher gave a question and asked them to describe something. In the teaching process also the teacher could give an easy explanation so the students could catch the lesson easily. In this cycle, the researchers conducted Classroom Action Research models that include planning, acting, observing, and reflecting. And the result of students' second-test was higher than the result of students' firsttest.

The mean score of students' first-test was 45 and the percentage was $12 \%$ who got above the KKM. There were 3 students who got a higher score and the 22 students got under the KKM and the lower score was 33, the higher score was 67. Meanwhile, the result of students' post-test started from the mean score was 76 and the percentage was $84 \%$ which there were 21 students got the score above the KKM, and 4 students got under the KKM.

It means that the English pop song improved the students listening ability because there was a significant improvement of students listening skill. Besides the English pop song made the learning process more interesting for the students. the use of English pop song able to enhance students' listening ability. It is supported by the result in every meeting which shown improvement, it is also supported by the result of Mean in the post-test which was 76 and the percentage was $84 \%$. It meant that using English pop song is significant to enhance students' listening ability.

\section{CONCLUSION}

The use of pop song needs to apply in the classroom as much as possible. Utilizing the technology for language teaching is of great importance, and the tendency to integrate technology with lesson content grows each day. Accordingly, utilizing songs through technology in a lesson environment attracts attention. There are positive and negative views 
on the utilization of songs in foreign language teaching. Using songs in the learning process especially in the listening lesson it makes a pleasant atmosphere in the class and makes the teachers explain the topic or the material easily. The students also can improve their listening skill as one of their meaningful strategies to overcome their problem in listening skill. English song can make the students become active in the class, they are interesting, and so they can do a listening task well. However, utilizing songs in the listening process has the challenges, such as; pop songs are not scientific, inefficient sound systems in schools may cause problems while listening to songs, the types of music favored by students may not be matching with each other, etc. Finally, we should bear in mind that every day our profession is more demanding and we have to be ready to face the challenges that come up, finding solutions or different alternatives.

\section{REFERENCES}

Brown, H. (2003). Language Assessment principle and Classroom PracticesNew York: person education.

Byrne, B. (1986) Self-Concept/Academic Achievement Relations: An Investigation of Dimensionality, Stability, and Causality. Canadian Journal of Behavioural Science, 18, 173-186. https://doi.org/10.1037/h0079982.

Fang, X. (2008). Listening comprehension in EFL Teaching. Retrieved October, 6, 2019 from www.linguist.org.com/doc/uc20080105,pdf.

Kemmis, S., Mctaggart, R., \& Nixon, R. (2014). The Action Research Planner: Doing Critical Participatory Action Research. Singapore: Springer. http://dx.doi.org/10.1007/978-981-4560-67-2.

Nihei, K. (2002). How to Teach Listening. Japan: EDRS.

Reina, A., \& Edgar, A. (2010). The use of songs as a tool to work on listening and culture in EFL classes. Cuadernos de Lingüística Hispánica, (15),121-138. https://www.redalyc.org/articulo.oa?id=3222/322227521008.

Richard, F. (2003). Understanding the Fundamentals of Classical Music. United Kingdom.

Rost, M. (2013). Listening in Language Learning. New York: Longman.

Zogota, N. (2011). Using Song, Music and Lyrics in English Teaching. Regovka: Nautreni secondary school. 